\title{
Population Forecast with Focus on Emigration: Scenarios for the Case of Peripheral Region
}

\author{
By Aleksejs Homutininins ${ }^{1}$, Viktorija Šipilova ${ }^{2}$ Ludmila Aleksejeva $^{3}$
}

\begin{abstract}
Sustainable decision-making and policies for regional development need clear understanding of future trends in population change. Emigration as one of the core factors of population change causes the greatest uncertainty in the demographic forecasts. Population change due to emigration is bright especially in peripheral regions what strengthens their unfavourable socio-economic conditions. Within the present study, the authors forecast population change due to emigration in peripheral region with high emigration rates. The authors offer three scenarios - current, half of current, and zero emigration, which demonstrate how differentiated population change due to emigration may be in case of different suppositions. Such approach focuses on the issue at local level. For numerical expression of population change, the authors apply simulation model based on system dynamics methods. Forecast results of future population change due to emigration in each scenario may be as a basis for timely inclusion of issues in regional development policies.
\end{abstract}

Keywords: population forecast, scenarios, emigration, peripheral region, regional development, system dynamics

\section{Introduction}

The European Union Territorial Agenda 2030 emphasises “... that development needs and impacts of future developments differ between places in Europe" (EU2020.de, 2020, p.16). Scientists and practitioners highlight that success of the European Union Territorial Agenda 2030 (EU2020.de, 2020) will depend on “... decision-making and policies at lower spatial scales" (Dr Cormac Walsh Research and Consulting, 2020). In such case, the success of decision-making and regional policies at local level will depend on "clearer" understanding of the future. As Mielczarek and Zabawa (2021, p. 1) indicate: "The credibility of the decisions taken by regional and national authorities often depends on the accuracy of population forecasts". In other words, the quality of local regional development policies and aims will rise, when numerical values of the future population trends will be known through forecasts.

In population forecasts, one of the core elements relates to emigration, especially in the cases of peripheral regions (e.g., European Commission, 2019). Scientists and policy makers indicate that continuing decline of population fortifies peripheral positions of economically weak regions, because population density affects development potential of regions (e.g., EU2011.hu, 2011; Camarero \& Oliva, 2019). Besides, in the age of Europe's economy transition towards place-based circular and climate-neutral model, human capital in regions continuing to be crucial factor among others (EU2020.de, 2020). 
There are some common factors, which stimulate emigration at regional level depopulation, low population density or high dispersion of population, accessibility of territory, availability of daily services, and possibilities to be mobile (Camarero \& Oliva, 2019), income inequality and low level of monthly wages (Laskiene, Zykiene, \& Verdnikovaite, 2020), brain drain and brain exchange (Maleszyk, 2021), homeownership (Palomares-Linares \& van Ham, 2020). The most of these characteristics may be addressed and improved through regional development policies (e.g., Davies \& Michie, 2011). In an ideal case, the aims addressing the main factors for population decline, for example, emigration, within regional development policies have to be based on population change forecast. Forecasting is a tool for understanding the scale of population change in case of differentiated scenarios.

Demographic forecasts in scientific literature covers economic and regional areas (e.g., Dykas, Mentel, \& Misiak, 2018; Bolińska et al, 2019; Miranda \& Lima, 2011; Fogel, 1994; Śleszyński, Kubiak, \& Korcelli-Olejniczak, 2020). In regional aspect, the focus is put on demographic issue of population change in territories with differentiated level of development (e.g., Śleszyński, Kubiak, \& Korcelli-Olejniczak, 2020), on population at working age and rural population (e.g., Parshukov et al. 2016).

Taking into account current aims of the territorial development (EU2020.de, 2020), forecasting at local level may reduce failure in aims in peripheral regions. Often, regions forecast measurable outcomes expected from the planned activities. At the same time, it is significant to forecast different scenarios of the demographic change for clearer planning of future activities including the above-mentioned measurable outcomes in social and economic areas.

Significance of demographic forecasting to economy is demonstrated by scientific research in the areas of, for example, investments and labour productivity (e.g. Bolińska et al, 2019), economic growth and number of employees (e.g. Dykas, Mentel, \& Misiak, 2018), gross domestic product (Miranda \& Lima, 2011), and economic policy (e.g. Fogel, 1994). However, focus mainly is made on forecasting at countries' level (e.g., OECD.Stat, 2021; Eurostat, 2021a, 2021c) and more seldom at the level of internal regions (e.g., Eurostat, $2021 b, 2021 d)$. Special focus has to be made on different scenarios of forecasting at regional level, because, as Park and Heim LaFrombois (2019) indicate, population forecasts have to be as basis for resource and service distribution and future needs within communities.

In the frames of the present study, the authors aim to offer three scenarios of population forecast with focus on emigration in the peripheral region, which experiences high emigration. The research results identify and numerically express possible negative trends of population decline in the peripheral region, because of emigration. Long-term forecast provides basis for timely development of appropriate regional policies preventing loss of critical mass of human capital and economic decline.

For the purpose, the authors focus on one peripheral region in Latvia and emigration as demographic process, which during long period causes negative socio-economic consequences for the region. Authors apply simulation model based on system dynamics methods for forecasting population change in case of three scenarios - current emigration, half of the current emigration, zero emigration.

Particularly, the article devotes attention to the case of Latgale region (Southeast of Latvia) 
because of the several reasons. Firstly, on the map of the European Union Territorial Agenda 2030, Latgale region is marked as region, which did not reach or exceed the value of GDP before economic and financial crisis in 2008-2009 three years in succession (Federal Institute for Research on Building, Urban Affairs and Spatial Development et al, 2020, p. 41). Secondly, in the National Development Plan of Latvia for 2021-2027, Latgale region is mentioned as region with population ageing (Cross-Sectoral Coordination Center, 2020). However, previously in National Development Plan for 2014-2020 (Cross-Sectoral Coordination Center, 2012), Latgale region demonstrated slight increase in territorial development index. Thirdly, in Development Programme of Latgale planning region 20202027 (Latgale Planning Region Development Council, 2020), Latgale region is mentioned as region with the fastest decline of population that reaches amount of $37-43 \%$ in some municipalities. Although, the positive tendency of light increase in amount of population in working age is observed during the last years (Latgale Planning Region Development Council, 2020). Fourthly, state, society, and entrepreneurship experts have recognised the population as the main driving force of the development of rural areas in Latgale region within the quantitative and the qualitative research (Šipilova et al, 2017).

According to the mentioned, population decline, which causes low economic capacity also, is the core issue for regional development in Latgale region. Emigration is recognised as one of the main reasons for population decline in the region (e.g., European Commission, 2019; Rajevska \& Romanovska, 2016; Latgale Planning Region Development Council, 2020, n.d.). Scientific studies indicate that emigration is undoubted result of peculiarities of peripheral regions (e.g., Camarero \& Oliva, 2019). Local planning documents in Latgale region aim to maintain population amount at the certain level through mechanisms of encouraging social and economic spheres (e.g. Latgale Planning Region Development Council, 2020) what needs understanding of population change in the long-term perspective.

The article is organized as follows. The second section offers literature overview on emigration in regional development context. Literature review emphasises necessity to forecast population change due to emigration at regional level. The third section describes data used and method applied for population change forecast. The fourth section, firstly, contains peculiarities of regional development in the chosen region for the case study according to the theoretical highlights and, secondly, provides three scenarios of population change forecast. The fifth section concludes the article.

\section{Emigration in Regional Development Context: Literature Overview}

Scientific studies and regional practices demonstrate that effects of emigration on regional development are not unambiguous. In terms of different theoretical approaches, effects from emigration may differ depending on the development level of region. In turn, individuals' decisions to emigrate are caused by differentiated economic and social reasons. For example, according to Staniscia's and Benassi's (2018) review of theoretical approaches, reasons, which encourage decisions concerning migration, may be understood from two points of view - personal reasons, which relate to income and quality of life and overall order in world economic relationships.

Labour markets of developed countries need additional labour force what is emphasized 
within dual labour market theory (Staniscia \& Benassi, 2018). Relationships between core and periphery are emphasised within world systems theory (Staniscia \& Benassi, 2018). According to these approaches, population moves from periphery to core, i.e. to economically stronger regions, where shortage in income and employment levels may be overcome. This logic relates to personal reasons.

Personal reasons encouraging emigration relate, firstly, to employment and income level, as indicated in neoclassical approach and, secondly, to family strategy of risk diversification, as indicated in new economics of migration (e.g., Staniscia \& Benassi, 2018). Moreover, Staniscia and Benassi (2018) in their research indicate that personal income and factors, which affect quality of life, are more relevant for explaining emigration than regional GDP.

There are several factors, which encourage emigration: depopulation, population density, population dispersion, accessibility, mobility, rurality (Camarero \& Oliva, 2019), employment, minimal monthly wages, income inequality (Laskiene, Zykiene, \& Verdnikovaite, 2020), brain drain (Maleszyk, 2021), homeownership (Palomares-Linares \& van Ham, 2020).

Effects of emigration for peripheral regions mostly are negative as far as such areas lost human capital and thus strengthen their peripheral characteristics. These effects are: continuing depopulation, demographic imbalance, territorial disadvantage (Camarero \& Oliva, 2019), "brain waste" (Laskiene, Zykiene, \& Verdnikovaite, 2020; Maleszyk, 2021), low economic development level.

Special attention scientists pay to emigration of the young population (Camarero \& Oliva, 2019). Maleszyk (2021) in the research highlight emigration age profile, when mostly young population are tended to emigrate. Special attention is devoted to university graduates, which are tended to emigrate from peripheral regions to economically higher developed regions (e.g., Maleszyk, 2021). As a result, young and well-educated population move from peripheral regions thus decreasing regional possibilities to overcome economic and social gap.

Emigration of young and well-educated population, i.e., brain drain, has negative effect on peripheral territory. Malecszyk (2021) calls this process the loss of talents. Another process, which is topical for the peripheral regions, is so called "brain waste". Laskiene, Zykiene, \& Verdnikovaite (2020) in their research mention that emigration of welleducated population due to economic reasons for employment in lower qualified positions is waste of human capital, i.e., brain waste, for the region-donor.

The way to address the issues of peripheral regions is realization of appropriate regional development policies. Davies and Michie (2011) classify regional policies for the peripheral regions indicating that not all countries choose to pay special attention to peripheral regions in their activities.

According to Davies and Michie (2011, p. 24, 26, 28) there are countries, where peripheral regions have a high profile (special separate documents elaborated), relatively high profile (regional policies have focus on peripheral regions) or only a regional profile (the problems of peripheral regions do not have a particularly high profile in the national context but are seen as important within minority of regions, some regional policy instruments cover peripheral regions among others and within individual regions may be more specific attention). In some extent the choice depends of how policy-makers view peripherality - 
remoteness of territory from large markets and core services or low population density, population decline, ageing (Davies \& Michie, 2011).

European Union's Cohesion policy (Davies \& Michie, 2011) and the European Structural and Investment Funds are used improving regional development conditions in sparsely and very sparsely populated regions (Camarero \& Oliva, 2019).

Camarero and Oliva (2019) indicate that the issues of development in peripheral regions and population decline are not specific problems, but general at the European scale.

Countries try to address the issues of peripherality through their regional policies. The experience of some countries confirms theoretical suppositions about quality of life as significant factor, which affects decision of migration, mentioned in research of Staniscia and Benassi (2018). For example, as Davies and Michie (2011, p. 32) indicate: "While many peripheral areas are experiencing outflows of more educated younger people ..., some are also seeing inflows of highly educated return-migrant or in-migrants who are attracted by the perceived quality of life of these areas in terms of the natural environment and social cohesion."

As far as scientists conclude that peripheral regions loss young population, which search for education possibilities (e.g., Maleszyk, 2021), some countries choose to invest in high education in peripheral regions. For example, Scandinavia and UK demonstrate approach of strong investments in high education in peripheral regions during long time (Davies \& Michie, 2011).

Decline of population due to economic reasons is highlighted in research (e.g., Laskiene, Zykiene, \& Verdnikovaite, 2020). Countries practice to establish public-sector agencies in peripheral regions for development of SME and attracting funding (Davies \& Michie, 2011).

Among factors that stimulate emigration, accessibility and mobility are mentioned as significant (e.g., Camarero \& Oliva, 2019). Regional policies address these issues through building social community enterprises, improving transport networks and broadband connectivity (Davies \& Michie, 2011).

However, each planned activity requires investments what relates to the amount of people living in the certain territory today and in the future. In the research on cities, Park and Heim LaFrombois (2019) indicate that population projections are significant for local development guidance, especially in cases of depopulation.

In the theoretical and empirical perspectives, emigration is a part of global and local economic flows with possible negative consequences for regions-donors, especially peripheral. Depopulation caused by emigration in peripheral regions may be addressed through regional development policies. As mentioned previously, personal income and quality of life are among core factors, which affect decisions to emigrate. Success in addressing these issues through regional development policies relates to clear understanding of future population change.

\section{Methodology and Data}

The authors aim to offer three scenarios of population forecast with focus on emigration for the peripheral region, which experiences high emigration. The research results identify and numerically express possible negative trends of population decline in 
peripheral region because of emigration. According to Krūminš̌ and Bērzinšs (2019), the forecasting of the expected migration trends causes the greatest uncertainty in the demographic forecasts. Additionally, forecasts at regional level are more complicated due to migration processes among others (Krūmiņš \& Bērziņš̌, 2019).

The authors apply simulation model based on system dynamics methods for forecasting population change in Latgale region (Southeast of Latvia) in case of three hypothetical scenarios - current emigration, half of the current emigration, zero emigration. The authors use ISEE iThink v.10.0.2 software for computer modelling.

Mathematically, the basic structure of a formal system dynamics computer simulation model is a system of coupled, nonlinear, first-order differential (or integral) equations (1), $\frac{d}{d t} x(t)=f(x, p), \quad$ [equation 1]

where $x$ is a vector of levels (stocks or state variables), $p$ is a set of parameters, and $f$ is a nonlinear vector-valued function (Richardson, 1991, p. 145).

Simulation of such systems is easily accomplished by partitioning simulated time into discrete intervals of length $d t$ and stepping the system through time one $d t$ at a time. Each state variable is computed from its previous value and its net rate of change $\chi(t)$ :

$\mathbf{x}(\mathbf{t})=\mathbf{x}(\mathbf{t}-\mathbf{d t})+\mathbf{d t} * \mathbf{x}(\mathbf{t}-\mathbf{d t})$ (Richardson, 1996, p. 807) [equation 2]

Limitations of research relate to supposition that in all scenarios level of fertility and mortality do not change.

For calculating dynamic of population structure by age and sex and for the higher precision of the model, aggregates are separated while sub-models are interconnected for female and male population development. Each sub-model includes 13 age groups: 0-14, 15-19, 2024, 25-29, 30-34, 35-39, 40-44, 45-49, 50-54, 55-59, 60-64, 65-69, from 70. The age group 0-14 refers to people under working age, the age group from 70 almost excludes active population, and therefore these two groups represent non-active population. Age groups from 15 and up to 69 represent labour force. Initial data for each age group is being imported from input data file and refers to year 1996. Transition from one age group $x$ to the next (maturing) is done according to equation presented in the equation (3):

Maturing [age group $x+1$ ] = population[age group $x$ ]/[age group $x$ size (years)] [equation 3]

The equation indicates, for instance, that all persons from age group "35-39" will move to the group " $40-44$ " within 5 years, but from group " $0-14$ " to the group " $15-19$ " within 15 years. The value of each age group $x$ at any time is calculated according to following equation (4):

Population [age group $\mathrm{x}](\mathrm{t})=$ population [age group $\mathrm{x}](\mathrm{t}-\mathrm{dt})+($ maturing[age group $\mathrm{x}-1$ ] - maturing [age group $\mathrm{x}+1$ ]) $* \mathrm{dt}$, [equation 4]

where

$\mathrm{t}$ - year of current calculations,

$\mathrm{dt}$ - time interval (1 year in case of the simulation model).

The model considers immigration, emigration and death factors as well, thus the complete equation is following (5):

population[age group $x](t)=$ population[age group $x](t-d t)+($ maturing[age group $x-1$ ] + immigration[age group $x$ ] - maturing[age group $x+1$ ] - deaths[age group $\mathrm{x}$ ] - emigration [age group $\mathrm{x}$ ]) $* \mathbf{d t}$, [equation 5] 
where

$\mathrm{t}$ - year of current calculations,

$\mathrm{dt}$ - time interval (1 year in case of the simulation model).

Calculation of number of births each year reinforces male and female age groups " $0-14$ ". Calculations are made by multiplication of fertile female population in the age group 1545 and data on fertility rate for each period. According to the mean value for recent 50 years, distribution between male and female new-borns is $49 \%$ for male and $51 \%$ for female.

The model has been tested in two stages - using critical initial values and comparing results returned by simulation for period 1996-2020 to historical ones. The deviations between simulated historical demographic results and statistical data are in range $+/-1 \%$.

Besides population, additional forecasts were calculated using following equations:

demographic_burden $(t)=\frac{\text { population[age group } 0-14](t)+\text { population }[\text { age group } 65+](t)}{\text { popuation }[a g \text { group } 15-64](t)}$ population[age group 15-64] $(t)$

[equation 6]

labor_force $(t)=$ population [age groups 15-64] $(t)$ [equation 7] preschool_children $(t)=$ population [age group 2-6] $(t)$ [equation 8] school_age_children $(t)=$ population [age group 5-19] $(t)$ [equation 9]

The authors use statistical data on population by sex, ethnicity, marital status and main age group in regions, cities and municipalities (Official Statistics Portal, Official Statistics of Latvia, 2021d), number of live births and stillbirths by sex (Official Statistics Portal, Official Statistics of Latvia, 2021b), deaths by sex and age (Official Statistics Portal, Official Statistics of Latvia, 2021c), international long-term migrants by age and sex (Official Statistics Portal, Official Statistics of Latvia, 2021a) from official statistical database in Latvia. The input data is prepared and structured.

Because of modelling, the following data can be presented from the model for three scenarios at any year up to 2074: population, demographic burden, preschool children, school age children, and labour force. The authors focus on the mentioned indicators because of their strong correlation with emigration. The results obtained from modelling are enough realistic because most of residents determining population development in the period analysed are already living today.

The authors focus on the case of Latgale region (Southeast of Latvia), which according to scientists and practitioners is recognized as peripheral (e.g., European Commission, 2019; Apsite-Berina, Burgmanis, \& Prusakova, 2020). The case of the region is valuable for study because of the following reasons: 1) the region experiences pronounced population decline due to emigration (Latgale Planning Region Development Council, 2020; European Commission, 2019), 2) from the view point of state, entrepreneurship and society experts, population is the main driving force of smart development in Latgale region (Šipilova et al, 2017). Thus, numerical understanding of possible population decline in the region may encourage timely addressing of the issues through regional development policies.

\section{Peculiarities of Regional Development and Scenarios of Population Change Due to Emigration in Latgale Region}

\subsection{Peculiarities of regional development}

The Regional Policy Guidelines 2021-2027 indicate the aim to provide solutions 
for the development of population density and quality of life in accordance with the specifics of the territories (Ministru Kabinets [Cabinet of Ministers], 2019).

In terms of depopulation and ageing as characteristics of peripherality (e.g., Davies \& Michie, 2011), Latgale region is understood as peripheral region (European Commission, 2019; Apsite-Berina, Burgmanis, \& Prusakova, 2020). According to European Commission (2019, p. 49) data: "Depopulation and exacerbated ageing of the society is heavily affecting peripheral regions" (Latgale region with Vidzeme and Kurzeme regions). According to scientific viewpoint, emigration is serious factor affecting demographic and economic processes in Latvia at regional level (e.g., Rajevska \& Romanovska, 2016; Latgale Planning Region Development Council, 2020, n.d.).

There are two main factors, which encourage emigration - personal income and quality of life (e.g., Staniscia \& Benassi, 2018). This section provides peculiarities of regional development in Latgale region, which relate to personal income and quality of life.

Latgale region has a twice higher poverty risk than capital city region (e.g., European Commission, 2019). Scientists conclude that emigration is ongoing due to an inadequate level of wages in Latvia (Rajevska \& Romanovska, 2016). For example, Ābeltiņa, Zvirgzdiña, and Zaringa (2015) devote attention to differences in employment, levels of income and investment, which stimulate misbalance in regional development and later may result in emigration. Laskiene, Zykiene, and Verdnikovaite (2020) in research on effects from income inequality on migration in the European Union indicate on the high income inequality rate and negative net migration rate in Latvia.

According to the Staniscia and Benassi (2018) and Laskiene, Zykiene, and Verdnikovaite (2020) personal income is among core factors stimulating decisions to emigrate. Moreover, this is not only theoretical supposition. In Latvia, inhabitants mention income as significant factor for decision to emigrate (e.g. DnB Nord Latvijas Barometrs, 2011).

Statistical data confirm that income level in Latgale region is the lowest in Latvia (Official Statistics Portal, Official Statistics of Latvia, 2021e). Although, household available income on average per household (euro per month) in Latgale region in 2019 increased 3.5 times comparing with 2004, income level in the region remains the lowest in Latvia under 1000 euros per person.

However, development strategy of Latgale region until 2030 aims to target negative tendency of low income level (Latgale Planning Region Development Council, 2020, n.d.). Income inequality is among main priorities in development strategies. Scientists conclude that there are positive tendencies in closing income gap between different groups of society, but not between regions Rutkovska, Brigmane (2018). According to Judrupa (2021), Latgale region is the less competitive region in Latvia, but equal and sustainable regional development is possible through well-developed regional policies. In Latgale region, $18 \%$ of inhabitants live in deep material deprivation and the region demonstrates the highest share of social benefits and pensions in income $(35 \%)$, and the level of social benefits and pensions is low (Rutkovska \& Brigmane, 2018). Consequently, high emigration level finds roots in unfavourable socio-economic conditions and Latgale region experiences the highest population decline among other regions (Rutkovska \& Brigmane, 2018). Inhabitants suppose that support for entrepreneurship and higher social guarantees are factors, which may prevent high emigration (DnB Nord Latvijas Barometrs, 2011). Mensikovs et al (2020, pp. 1223-1224) offer other point of view by indicating that 
economic poverty and inequality have to be measured not by the Gini index, but by access to quality education, healthcare and basic needs. According to the research of Mensikovs et al (2020), 74.2\% of the total poor population in Latgale region are "resource-poor" and $20.4 \%$ "resource-functional" poor. Each group needs differentiated approach from regional development policy (Mensikovs et al, 2020).

One more reason, which is considered as core for decisions to emigrate relate to factors, which affect quality of life (e.g., Staniscia \& Benassi, 2018). Moreover, practices of regions demonstrate that perceived quality of life may stimulate flows of return-migrants and inmigrants (e.g., see Davies \& Michie (2011, p. 32) for the case of regional development policies in Northern Europe).

Data on quality of life in Latgale region are available from the "Atlas for the Territorial Agenda 2030. Maps on European Territorial Development” (Federal Institute for Research on Building, Urban Affairs and Spatial Development et al, 2020). In terms of Life Maintenance Index (personal health, personal safety, healthy economy, healthy society, healthy environment, and climate change), Latgale region is ahead of other Latvian regions (Federal Institute for Research on Building, Urban Affairs and Spatial Development et al, 2020, p. 36). However, in terms of Life Flourishing Index (self-esteem, self-actualization, interpersonal trust/societal belonging, institutional trust/good governance, biodiversity wealth), Latgale region (with Zemgale region) is behind other Latvian regions (Federal Institute for Research on Building, Urban Affairs and Spatial Development et al, 2020, p. 36).

Nowadays regional potential of green infrastructure also is considered as significant factor affecting quality of life. Green infrastructure is understood as activities of "supporting a green economy, improving quality of life, protecting biodiversity and enhancing the ability of ecosystems to deliver services such as disaster risk reduction, water purification, air quality, space for recreation and climate change mitigation and adaption" (Trinomics et al, n.d., p.1). According to the data on regional potential of green infrastructure in Latgale region, such potential is moderate comparing with some other Latvian regions (Federal Institute for Research on Building, Urban Affairs and Spatial Development et al, 2020, p. 65). However, Latgale is home to Razna National Park, Nature Park "Daugavas Loki" and several nature reserves and nature parks that are part of Natura 2000 territories (Latgale Planning Region Development Council, 2020). Natura 2000 network significantly helps to protect healthy ecosystems (Trinomics et al, n.d., p.1).

According to the data on protected areas (Federal Institute for Research on Building, Urban Affairs and Spatial Development et al, 2020, p. 73), proportion of protected areas defined by European and national legislation in Latgale region is from 10 to $25 \%$. This is relatively high result. Research results on opinions of inhabitants of protected areas in Latvia discover that: "People living in protected nature territories admit that it is much healthier to live in these territories compared to other places in Latvia" (Riga Stradiņš University, 2016). However, research results discover insufficient level of information and understanding among inhabitants in protected areas about nature pollution. According to research (Riga Stradinsš University, 2016): "The overall level of satisfaction with the quality of life (including all aspects of quality of life) of respondents in all areas is 65\%, which can be assessed as average".

Estimated change of nitrogen oxide (NOx) emissions from 2020 to 2030 in \% in 
Daugavpils city (the second biggest city in Latvia and the biggest city in Latgale region) is relatively high and despite definitely lower population is similar as in the biggest cities of Europe (Federal Institute for Research on Building, Urban Affairs and Spatial Development et al, 2020, p. 71). It is noteworthy that two cities of Latgale region (Daugavpils and Rezekne) provides $1 / 2$ of value added produced in the Latgale region (Rutkovska \& Brigmane, 2018).

Scientists pay attention to the improvements made in urban environment and landscape quality in Latvia, however, at the same time depopulation processes still are topical (e.g., Matisovs, 2011).

Some countries emphasize potential of peripheral regions (Davies \& Michie, 2011). Due to the diverse landscapes, many lakes and rivers, and protected areas with unique flora and fauna, Latgale is a great tourist destination (Rutkovska \& Brigmane, 2018). However, the greatest meaning has to be devoted to population in region. Research results demonstrate that in Latgale region, population according to the state, entrepreneurship and society experts' viewpoints and statistical calculations has the closest linkage with development process within the concept of smart specialization strategy (Šipilova et al, 2017). According to the experts' opinions the factors affecting smart specialization of Latgale region in dimension population are: readiness and capacity to become entrepreneur, the use of available resources for increasing prosperity, involvement in formal and non-formal education, development and implementation of innovative ideas (Šipilova et al. 2017, p. 98). Thus, decrease in the number of population causes a situation, when significant factor for realization of smart specialization strategy in Latgale region is not sufficient in quantity and quality.

Not only scientific research results, inhabitants also confirm that emigration is threat to rural development due to the declining population (DnB Nord Latvijas Barometrs, 2011). Confirmation of the great role of population in the process of regional development in Latvian regions can be seen also in research of Rivza et al (2017), where readiness of local community for active, innovative and inclusive activities are considered as crucial among others.

In conclusion, in terms of personal income, Latgale region demonstrates unfavourable conditions - the income level is lower than in average in Latvia and poverty risk is higher (e.g., European Commission, 2019; Official Statistics Portal, Official Statistics of Latvia, 2021e; Rutkovska \& Brigmane, 2018). In terms of quality of life, Latgale region mostly maintain quality of life than flourish (e.g, Federal Institute for Research on Building, Urban Affairs and Spatial Development et al, 2020, p. 36). However, the region has sufficient potential in terms of green environment (e.g., Rutkovska \& Brigmane, 2018; Federal Institute for Research on Building, Urban Affairs and Spatial Development et al, 2020, p. 73; Latgale Planning Region Development Council, 2020).

\subsection{Scenarios of population change due to emigration}

According to OECD population forecasts, (OECD.Stat, 2021), population in Latvia will decrease during the next ten years. Overall population decline may reach about 9\% from 2020 to 2030 (calculations made using OECD.Stat, 2021). According to Eurostat population forecast for the year 2030 (Eurostat, 2021c), population decline will reach similar value of about 10\% (calculations made using Eurostat, 2021c). Eurostat database 
offers also longer perspective until 2100. According to this data (Eurostat, 2021c), population decrease in Latvia in 2100 comparing with 2020 will reach about $43 \%$ (calculations made using Eurostat, 2021c). This result is the worst in the European Union. In general, there are sixteen countries in the European Union, which will experience serious population decrease in 2100 in amount from 20\% to 43\% (calculations made using Eurostat, 2021c). The highest and similar values of population decrease in 2100 will be observed also in Lithuania (about 39\%) (calculations made using Eurostat, 2021c).

Population forecasts at regional level are provided seldom. In Europe, population forecasts at regional NUTS 3 level are available in Eurostat database (Eurostat, 2021d). According to Eurostat (2021d), in Latgale region, population decline is forecasted. In 2030 comparing with 2020, population decline may reach about 18\% (calculations made using Eurostat, 2021d). In 2100 comparing with 2020, this result may reach about 60\% (calculations made using Eurostat, 2021d).

Assumptions for net migration indicate that Latvia will has negative net migration in 2030 and positive in 2100 (Eurostat, 2021a). The change from negative to positive net migration values and gradual increase of positive values are expected in 2065 (Eurostat, 2021a). In Latgale region, similar situation is expected to be observed since 2059 (Eurostat, 2021b). Population forecasts for Latvia and regions are offered by scientists as well (e.g., Krūmiņš \& Bērzinsš, 2019). According to this research, population in Latvia will decrease and especially in Latgale region (and Vidzeme region) (Krūminsš \& Bērzinş̌š, 2019).

Taking into account forecasted population decline (e.g., OECD.Stat, 2021; Eurostat, 2021 c, 2021d; Kruminsš \& Bērzinşš, 2019), different scenarios of population change may be a useful tool for regional development policy aims. As one can see, there is no different scenarios in statistical data and scientific studies do not focus on different scenarios as well.

In the development documents of Latgale region until 2027 and 2030, there are specific goals devoted to population change. Development aims of the region are set to reduce negative demographic and migration processes and maintain population between 220 thousands and 300 thousands (depending of the planning document), to reduce the impact of the negative demographic trend on the region by making the region more attractive (Latgale Planning Region Development Council, 2020, n.d.).

As a result of application of simulation model based on system dynamics methods, the authors offer forecasts of population change in Latgale region because of emigration for three scenarios (current emigration, half of the current emigration, zero emigration). Figure 1 summarizes research results (see Figure 1) and Table 1 in Appendix offers numerical values of forecasts. 

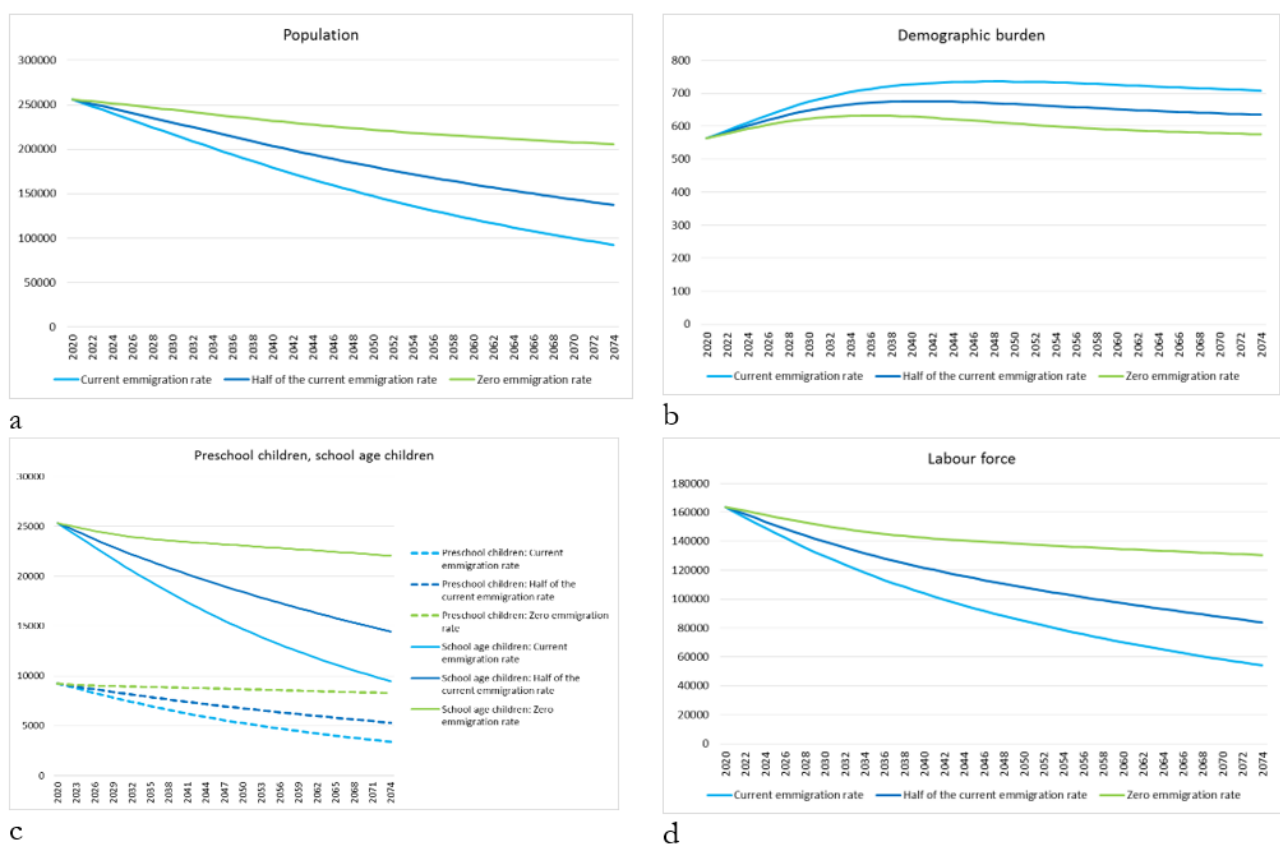

Note: For numerical values for the years 2020 (base year), 2030 (year set in development strategy of Latgale region), 2047 (middle of the forecast period), and 2074 (end of the forecast period) see Table 1 in Appendix.

Figure 1: Scenarios of population change due to emigration in Latgale region (Southeast of Latvia) until 2074

Source: authors calculations using Official Statistics Portal, Official Statistics of Latvia, 2021a, 2021b, 2021c, $2021 d$.

Population (see Figure 1a). According to three scenarios, population will decrease during the next 54 years in Latgale region. However, the scale of decrease significantly differs depending on the intensity of emigration.

In case of scenario "current emigration", population in 2074 in Latgale region may decline by about $64.0 \%$ comparing with the data in 2020 . According to the scenario of "current emigration", population amount will go below 200 thousands already in 2035, and below 100 thousands in 2070. Thus, the data analysed demonstrate that population decline because of emigration may be about 58294 people during the next 15 years, and about twice higher during the next 39 years from 2035 till 2074.

Scenario of "zero emigration" mostly is theoretical than realistic. Although, this scenario demonstrates that regional development policies have to target factors, which cause emigration, for more sustainable path of development in Latgale region. According to the scenario "zero emigration", population amount in Latgale region in 2074 may be smaller by about $20 \%$ than in 2020 . This result is three times better than for the scenario "current emigration". In this case, the overall process of population decline may be slower and population amount will not go below 200 thousands during the all period under research. Scenario "half of current emigration", although, demonstrates better results than scenario "current emigration", overall population decline in 2074 in Latgale region is brightly unfavourable and may reach $46.5 \%$. This scenario highlights how urgent the timely activities of regional development policies have to be for preventing continuing emigration 
from region due to unfavourable socio-economic conditions.

Taking into account specific aims of development strategy of Latgale region until 2030 (Latgale Planning Region Development Council, n.d.), it is noteworthy to highlight that according to the forecasts, the aim to maintain population at the level of 220 thousands (aim set in Latgale Planning Region Development Council, 2020) may not be reached. In 2030, according to the forecasts, population comparing with 2020 may decline in Latgale region by about $15 \%$ (scenario "current emigration"), $10 \%$ (scenario "half of current emigration") and 4.5\% (scenario "zero emigration").

Demographic burden (see Figure 1b). As a result of population decline because of emigration, demographic burden will increase. Higher demographic burden is forecasted in case of all three scenarios, but dynamic of demographic burden growth is differentiated.

In case of scenario "current emigration", demographic burden may increase from 2020 until 2051 and then to start slight decrease. Although, demographic burden in Latgale region in 2074 still is forecasted significantly higher than in 2020 (708 and 563 accordingly). Scenario "zero emigration" also demonstrates changes in dynamic. Although, in this case decrease of demographic burden may start earlier, already in 2036. This scenario also demonstrate that demographic burden at the beginning and end of the period analysed mostly is similar (563 in 2020 and 576 in 2074) comparing with other two scenarios.

Scenario "half of current emigration" offers demographic burden growth from 2020 until 2042 and then gradual decrease until 2074. Similarly as for other two scenarios, demographic burden in Latgale region in 2074 may be higher than in 2020.

Changes in population at regional level significantly affect regional potential in terms of future generations (i.e., preschool children and school age children) and labour force.

Labour force (see Figure 1d). Three scenarios demonstrate that labour force amount may decrease in Latgale region in 2074 by about 67\% (scenario "current emigration"), 49\% (scenario "half of emigration"), and 20\% (scenario "zero emigration"). In case of "current emigration" labour force decline may go below 100 thousands in 2042, in case of "half of current emigration" 16 years later, and in case "zero emigration" may remain over 100 thousands during the all period analysed.

Preschool children and school age children (see Figure 1c). Changes in amount of preschool children in Latgale region during the period analysed significantly differ in case of "zero emigration" and other two scenarios. In case of "zero emigration", number of preschool children decreases only about $10 \%$, when in cases of "current emigration" and "half of current emigration" by $63 \%$ and $42 \%$ accordingly. Similar tendency may be observed for changes in number of school age children. According to the data forecasted, number of school age children in Latgale region in 2074 may decrease in any scenario, but in the case of "zero emigration" by only $13 \%$ and in cases of scenarios of "current emigration" and "half of current emigration" by $63 \%$ and $43 \%$ accordingly.

The present study expand the existing population forecasts by focusing on differentiated scenarios at regional level. In general, amount of young population and labour force will decline and demographic burden will increase. These tendencies require special attention from regional development policies.

A regional policy is needed to increase population growth. According to the population, reducing social inequalities and emigration is as important as promoting birth rates (e.g., Krumiņš \& Bērziņšs, 2019). 
The research results offer numerical expression of population change due to emigration in three scenarios, which may be applied for elaboration of regional development strategies in Latgale region.

\section{Conclusions}

The New Territorial Agenda of the European Union stimulates debates that decision-making at local level will affect overall success in regional development and this success will depend on population forecasts (e.g., EU2020.de, 2020; Dr Cormac Walsh Research and Consulting, 2020; Mielczarek \& Zabawa, 2021; Park \& Heim LaFrombois, 2019).

Population forecasts may be obtained from statistical databases such OECD (OECD.Stat, 2021), Eurostat (Eurostat, 2021c) etc. However, the issue requires additional attention from scientists, because population forecasts at regional level are seldom (e.g., Eurostat offers population forecasts at NUTS 3 level for the European Union countries, e.g. Eurostat, 2021d) and statistical databases do not offer differentiated scenarios, which may be of high importance for clearer design of regional development strategies in each case. Nowadays regions, especially those with peripheral characteristics, may address emigration issues through regional development policies. According to research results (Staniscia \& Benassi, 2018), emigration mostly are caused by level of personal income and factors affecting quality of life. Emigration effects mostly are negative for peripheral regions with negative net migration rates and population ageing. Thus, emigration is significant factor, which has to be taken into account for population forecasts at regional level.

Within the present study, the authors demonstrate how differentiated the results of forecast may be in case of different suppositions. The authors offer three scenarios of population forecast with focus on emigration level - current emigration, half of current emigration and zero emigration. The authors offer the case of Latgale region (Southeast of Latvia) for presentation of long-term population change in peripheral region, where high population decline is accompanied with recognition by the state, entrepreneurship and society experts that exactly population is core factor for smart development in Latgale region.

The scenario "current emigration" means situation, when regional development policies will not focus on emigration issues or will address them unsuccessfully. The scenario "half of current emigration" means situation, when high attention from regional development policies will be devoted to the issues of emigration. The scenario "zero emigration" is not realistic. This scenario is presented for comparison and demonstration of negative effects from current emigration on population change and for highlighting significance of wellgrounded regional development strategies.

Development documents of Latgale region (Latgale Planning Region Development Council, 2020 , n.d.) aim to maintain population amount at the level of 220 thousand people and increase until 300 thousand people. All three scenarios demonstrate that emigration will not allow increasing population until 300 thousand people. However, the scenario "half of current emigration" allows to maintain population amount over 220 thousands in 2030 and then demonstrates sequent decline below 200 thousand until 2047 and 2074. Only the scenario "zero emigration" will allow maintaining population over 200 thousand until 2074. Population change forecasts demonstrate that regional development policies have to address 
emigration issues as prioritised. According to experts and population viewpoints, increasing income level, decline in income differentiation, increase in employment, improved quality of life may prevent high emigration rates and even encourage remigration. The forecasts made indicate that critical point in population change in case of "current emigration" is in 2030. For example, tools of the European Union Regional Development and Cohesion Policy 2021-2027 (European Commission, 2018) are significant and have to be applied for improvements in income level and quality of life in the region.

The negative effects of population decline due to high emigration result in decline of next generations and labour force. These tendencies are observed as a result of population change due to emigration according to the calculations made. These data are significant for future resource and service distribution at regional level.

\section{References}

Ābeltina, A., Zvirgzdiṇa, R., \& Zariṇa, V. (2015). Sustainable development perspectives for Latvian regions. Vide. Tehnologija. Resursi - Environment, Technology, Resources, 2, 13-19. DOI: 10.17770/etr2015vol2.265

Apsite-Berina, E., Burgmanis, G., \& Prusakova, L. (2020). Reǵionālā cilvēkkapitāla nelīdzsarotība: jauniešu migrācija Latvijā [Regional human capital disequilibria: the case of youth migration in Latvia]. Folia Geographica, XVIII New Geographies of Wellbeing: Nature, Resources, Populations and Mobilities, pp. 28-35. Doi: $10.22364 /$ fg.18.4

Bolińska, M., Dykas, P., Mentel, G., \& Misiak, T. (2019). Demographic forecasts and volatility of investment rates vs. Labor productivity trajectories. Journal of Business Economics and Management, 20(6), 10451063. https://doi.org/10.3846/ibem.2019.10446

Camarero, L., \& Oliva, J. (2019). Thinking in rural gap: mobility and social inequalities. Palgrave Communications, Humanities, Social Sciences, Business, 5, 95. https://doi.org/10.1057/s41599-019-0306-x

Cross-Sectoral Coordination Center. (2020). National Development Plan of Latvia for 2021-2027. Approved on 2 July 2020 by decision of the Saeima of the Republic of Latvia, No. 418/Lm13. Retrieved from https://www.pkc.gov.lv/sites/default/files/inline-files/NAP2027 ENG.pdf

Cross-Sectoral Coordination Centre. (2012). National Development Plan of Latvia for 2014-2020. Approved by a Decision of the Saeima on 20 December 2012. Retrieved from https://www.pkc.gov.lv/sites/default $\angle$ files/inline-files/NDP2020\%20English\%20Final 1.pdf

Davies, S., Michie, R. (2011). Peripheral Regions: A Marginal Concern? EoRPA Paper 11/6. European Policies Research Centre, University of Strathclyde. Retrieved from https://www.eprc-strath.eu/public Ldam/jcr:2d3d3259-8f99-4769-9576-196531a32ff2/EoRPA\%20paper\%202011-6.pdf

DnB Nord Latvijas Barometrs. (2011). Numura tèma: Emigräiza [Topic of the issue: Emigration]. Nr. 35.

Dr Cormac Walsh Research and Consulting. (2020, 3 December). EU Territorial Agenda 2030 - Place-based development for a Just and Green Europe. Retrieved from https://cormacwalsh-consult.eu/2020 $\angle 12 / 03 /$ taeu-2030/

Dykas, P., Mentel, G., \& Misiak, T. (2018). The neoclassical model of economic growth and its ability to account for demographic forecast. Transformations in Business and Economics, 17(2B), 684-700.

EU2011.hu. (2011). Territorial Agenda of the European Union 2020. Towards an Inclusive, Smart and Sustainable Europe of Diverse Regions. Agreed at the Informal Ministerial Meeting of Ministers responsible for Spatial Planning and Territorial Development on 19th May 2011 Gödöllo", Hungary. Retrieved from https://www.territorialagenda.eu/files/agenda theme/agenda data/Background $\% 20-\% 20$ ESDP $\% 20$ and $\% 20 \mathrm{TA} /$ territorial agenda 2020.pdf

EU2020.de. (2020). Territorial Agenda 2030. A future for all places. Informal meeting of Ministers responsible for Spatial Planning and Territorial Development and/ or Territorial Cohesion 1 December 2020, Germany. Retrieved from https://ec.europa.eu/regional policy/sources/docgener/brochure/territorial agenda 2030 en.pdf

European Commission. (2019). Commission StaffWorking Document. Country Report Latvia 2019. Accompanying the document Communication from the Commission to the European Parliament, The European Council, The Council, The European Central Bank. and the Eurogroup. 2019 European Semester: Assessment of progress on structural reforms, prevention and correction of macroeconomic imbalances, and results of in-depth reviens under Regulation (EU) No 1176/2011. Retrieved from https://eur-lex.europa.eu/legal-content/EN/TXT/PDF/?uri=CELEX:52019SC1013\&from=FR 
European Commission. (2018). Regional Development and Cohesion Policy 2021-2027. Retrieved from https://ec.europa.eu/regional policy/en/newsroom/news/2018/06/06-08-2018-regionaldevelopment-and-cohesion-policy-2021-2027

Eurostat. (2021a). Assumptions for net migration by age, sex and type of projection. [Dataset]. Retrieved from https://ec.europa.eu/eurostat/databrowser/view/proj 19nanmig/default/table?lang=en

Eurostat. (2021b). Assumptions for net migration by age, sex, type of projection and NUTS 3 region. [Dataset]. Retrieved from https://ec.europa.eu/eurostat/databrowser/view/proj_19ranmig3/default/table?lang=en

Eurostat. (2021c). Population on 1st January by age, sex and type of projection. [Dataset]. Retrieved from https://ec.europa.eu/eurostat/databrowser/view/proj_19np/default/table?lang=en

Eurostat. (2021d). Population on 1st January by age, sex, type of projection and NUTS 3 region. [Dataset]. Retrieved from https://ec.europa.eu/eurostat/databrowser/view/proj_19rp3/default/table?lang=en

Federal Institute for Research on Building, Urban Affairs and Spatial Development, Schmidt-Seiwert, V., Duvernet, C., Hellings, A., Binot, R., Kiel, L., Thul, B., European Territorial Observatoru Network, Gauk, M. (2020) Atlas for Territorial Agenda 2030. Maps on European Territorial Development. EU2020.de. Retrieved from https://www.atlasta2030.eu/en/content/Atlas-TA2030 EN.PDF

Fogel, R.W. (1994). Economic growth, population theory, and physiology: the bearing of long-term processes on the making of economic policy. American Economic Review, 84(3), 369-395.

Judrupa, I. (2021). Regional competitiveness as an aspect promoting sustainability of Latvia. European Journal of Sustainable Development, 10(1), 650-667. DOI: 10.14207/ejsd.2021v10n1p650

Krūminnš J., Bērziņ̧̌̌ A. (2019). Demogrāfiskās attīstības vērtējumi un prognozes [Demographic development estimates and forecasts]. In Z., Krišjāne, J., Krūmiņš (Eds.). Tautas ataudze Latvija un sabiedrïbas atjannošanas izaicinajumi [Population Reproduction and Challenges for Renewal of Society in Latvia] (pp. 273285). Riga: LU Akadēmiskais apgāds. http://doi.org/10.22364/talsai.27

Laskiene, D., Zykiene, I., \& Verdnikovaite, P. (2020). Assessment of the Impact of Income Inequality on Population's Migration. Inæinerine Ekonomika-Engineering Economics, 31(5), 547-557. http://dx.doi.org/10.5755/j01.ee.31.5.25193

Latgale Planning Region Development Council. (2020). Latgales plānošanas reǵiona attīstïbas programma 2020-2027 [Latgale Planning Region Development Program 2021-2027. year]. Retrieved from https://lpr.gov.lv/wpcontent/uploads/2006/planosana/0-PROGRAMMA.pdf

Latgale Planning Region Development Council. (n.d). Latgales startệgija 2030 [Latgale Strategy 2030]. Retrieved from https://lpr.gov.lv/wp-content/uploads/2011/lpr-planosanas-dokumenti/Latgales strategija 2030 apstiprinata $01.12 .2010 . p d f$

Maleszyk, P. (2021). Outflow of Talents or Exodus? Evidence of youth emigration from one of the EU's peripheral regions in Poland. Region, 8(1), 33-51. DOI: 10.18335/region.v8i1.283

Matisovs, I. (2011). Urban development trends in the Latgale region at the beginning of the 21 st century. Vide. Tehnologija. Resursi - Environment, Technology, Resources, 1, 130-138. DOI: 10.17770/etr2011vol1.906

Mensikovs, V., Kokina I., Komarova, V., Ruza, O., \& Danilevica, A. (2020). Measuring multidimensional poverty within the resource-based approach: a case study of Latgale region, Latvia. Entrepreneurship and Sustainability Issues, 8(2), 1211-1227. http://doi.org/10.9770/jesi.2020.8.2(72)

Mielczarek, B., \& Zabawa, J. (2021). Modelling demographic changes using simulation: Supportive analyses for socioeconomic studies. Socio-Economic Planning Sciences, 74, Article number 100938. DOI: 10.1016/j.seps.2020.100938

Ministru Kabinets [Cabinet of Ministers]. (2019). Par Reğionäläs politikas pamatnostädnèm 2021.-2027. gadam. [On the Regional Policy Guidelines 2021-2027. year]. Retrieved from https://likumi.lv/ta/id/310954-parregionalas-politikas-pamatnostadnem-2021-2027-gadam

Miranda, L.C.M., \& Lima, C.A.S. (2011). On the forecasting of the challenging world future scenarios. Technological Forecasting and Social Change, 78(8), 1445-1470. DOI: 10.1016/j.techfore.2011.04.001

OECD.Stat. (2021) Population projections. Retrieved from https://stats.oecd.org/Index.aspx?DataSetCode $=$ POPPROJ

Official Statistics Portal, Official Statistics of Latvia. (2021a). IBE030. International long-term migrants by age and sex by Indicator, Age group, Sex and Time period. [Dataset]. Retrieved from https://data.stat.gov.lv Lpxweb/en/OSP PUB/START POP IB IBE/IBE030/

Official Statistics Portal, Official Statistics of Latvia. (2021b). IDS010. Number of live births and stillbirths by sex by The sex of the newborn, Indicator and Time period. [Dataset]. Retrieved from https://data.stat.gov.lv Lpxweb/en/OSP PUB/START POP ID IDS/IDS010/ 
Official Statistics Portal, Official Statistics of Latvia. (2021c). IMV010. Deaths by sex and age by Sex, Age and Time period. [Dataset]. Retrieved from https://data.stat.gov.lv/pxweb/en/OSP PUB/START POP IM IMSV/IMV010/

Official Statistics Portal, Official Statistics of Latvia. (2021d). IRG030. Population by sex, ethnicity, marital status and main age group in regions, cities and municipalities at the beginning of the year 2020 - 202. [Dataset]. Retrieved from https://data.stat.gov.lv/pxweb/en/OSP PUB/START POP IR IRG/IRG030/

Official Statistics Portal, Official Statistics of Latvia. (2021e). MIS030. Households disposable income in regions (euro per month) by Territorial unit, Indicator and Time period. [Dataset]. Retrieved from https://data.stat.gov.lv/pxweb/lv/OSP PUB/START POP MI MIS/MIS030

Palomares-Linares, I., \& van Ham, M. (2020). Understanding the effects of homeownership and regional unemployment levels on internal migration during the economic crisis in Spain. Regional Studies, 54(4), 515-526. https://doi.org/10.1080/00343404.2018.1502420

Park, Y., \& Heim LaFrombois, M.E. (2019). Planning for growth in depopulating cities: An analysis of population projections and population change in depopulating and populating US cities. Cities, 90, 237-248. https://doi.org/10.1016/i.cities.2019.02.016

Parshukov, D.V., Khodos, D.V., Pyzhikova, N.I., Vlasova, E.Y. (2016) Evaluation and forecast of demand for labor force of the agrarian sector of economy (Regional aspect). Journal of Advanced Research in Law and Economics, 7(7), 1812-1821. DOI: 10.14505/jarle.v7.7(21).28

Rajevska, F., \& Romanovska L. (2016). Latvia: Both Sides of the Economic Recovery Success Story. In K., Schubert, P., de Villota, \& J. Kuhlmann (Eds.). Challenges to European Welfare Systems (pp. 473-495). Springer, Cham. https://doi.org/10.1007/978-3-319-07680-5_21

Richardson, G.P. (1991). System dynamics: Simulation for policy analysis from a feedback perspective. In P.A., Fishwick, \& P.A. Luker (Eds.). Qualitative simulation modeling and analysis. Advances in Simulation, vol 5. (pp. 144-169). New York, NY: Springer-Verlag.https://doi.org/10.1007/978-1-4613-9072-5_7

Richardson, G.P. (1996). System Dynamics. In S.I., Gass, C.M., Harris (Eds.). Encyclopedia of Operations Research and Management Science (pp. 807-810). Norwell MA: Kluwer Academic Publishers.

Riga Stradiňš University. (2016, March 11) Pétijums: Vai ïpaši aiæsargäjamo dabas teritoriju iedఇìvotäji ir gatavi ilgtspejjgai saimniekošanai un dabas resursu izmantošanai? Preses relīe [Research: Are the inhabitants of specially protected nature territories ready for sustainable management and use of natural resources? Press release]. Retrieved from https://www.rsu.lv/aktualitates/petijums-vai-ipasi-aizsargajamo-dabas-teritoriju-iedzivotajiir-gatavi-ilgtspejigai

Rivza, B., Kruzmetra, M., \& Zaluksne, V. (2017). Through economic growth to the viability of rural space. Agronomy Research, 15(5), 2079-2089. DOI: 10.15159/AR.17.057

Rutkovska A., Brigmane M. (2018) Kä attistās Latvijas reǵioni? [How are Latvia's regions developing? Makroekonomika. Latvijas Banka. [Macroeconomics. Bank of Latvia]. Retrieved from https://www.makroekonomika.lv/ka-attistas-latvijas-regioni

Šipilova, V., Ostrovska, I., Jermolajeva, E., Aleksejeva, L., \& Oḷehnovičs, D. (2017). Evaluation of Sustainable Development in Rural Territories in Latgale Region (Latvia) by Using the Conception of Smart Specialization. Journal of Teacher Education for Sustainability, 19(1), 82-105. DOI: https://doi.org/10.1515/ites-2017-0006

Śleszyński, P., Kubiak, L., Korcelli-Olejniczak, E. (2020). A demographic forecast for Warsaw. Przeglad Geograficzny, 92(4), 475-497. DOI: 10.7163/PrzG.2020.4.2

Staniscia, B., \& Benassi, F. (2018). Does regional development explain international youth mobility? Spatial patterns and global/local determinants of the recent emigration of young Italians. Belgeo [Online], 3. Retrieved from http://journals.openedition.org/belgeo/30305 DOI: 10.4000/belgeo.30305

Trinomics, Alterra, Arcadis, Regional Environment Centre, Risk \& Policy Analysis, \& Stella Consulting (n.d.). Green Infrastructure in Latvia. Retrieved from https://ec.europa.eu/environment/nature/ecosystems /pdf/Green\%20Infrastructure/GI LT.pdf 


\section{Appendix}

Table 1: Numerical values of population change due to emigration in Latgale region (Southeast of Latvia) until 2074 in three scenarios

\begin{tabular}{|c|c|c|c|c|c|c|c|c|c|c|c|c|c|c|c|}
\hline $\begin{array}{c}\text { Forecasted } \\
\text { indicators }\end{array}$ & \multicolumn{3}{|c|}{ Population } & \multicolumn{3}{|c|}{$\begin{array}{l}\text { Demographic } \\
\text { burden }\end{array}$} & \multicolumn{3}{|c|}{$\begin{array}{l}\text { Preschool } \\
\text { children }\end{array}$} & \multicolumn{3}{|c|}{$\begin{array}{l}\text { School age } \\
\text { children }\end{array}$} & \multicolumn{3}{|c|}{$\begin{array}{l}\text { Labour } \\
\text { force }\end{array}$} \\
\hline 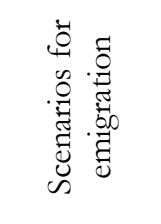 & 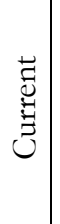 & 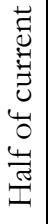 & $\stackrel{\circ}{\stackrel{U}{N}}$ & U్, & 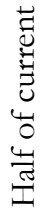 & $\stackrel{\stackrel{0}{N}}{N}$ & 苞 & 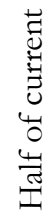 & $\stackrel{0}{\stackrel{D}{N}}$ & 节 & 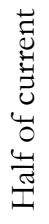 & $\stackrel{0}{\stackrel{U}{N}}$ & 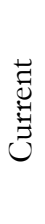 & 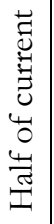 & $\stackrel{\circ}{\stackrel{D}{N}}$ \\
\hline 2020 & \multicolumn{3}{|c|}{255968} & \multicolumn{3}{|c|}{563} & \multicolumn{3}{|c|}{9213} & \multicolumn{3}{|c|}{25322} & \multicolumn{3}{|c|}{163758} \\
\hline 2030 & $\begin{array}{l}\stackrel{2}{\infty} \\
\infty \\
\infty \\
\stackrel{0}{\sim} \\
\sim\end{array}$ & 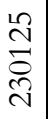 & $\begin{array}{l}\hat{\delta} \\
\stackrel{\overbrace{}}{J} \\
\stackrel{N}{N}\end{array}$ & $\frac{5}{6}$ & $\stackrel{\infty}{\sigma}^{\infty}$ & กิ & $\stackrel{1}{尺}$ & $\underset{\infty}{\stackrel{0}{\infty}}$ & $\begin{array}{l}\bar{\sigma} \\
\infty\end{array}$ & $\stackrel{\stackrel{\curvearrowright}{\sim}}{\stackrel{\sim}{\sigma}}$ & $\begin{array}{l}\overrightarrow{\hat{\sigma}} \\
\text { ปे }\end{array}$ & $\underset{\underset{\sim}{\sim}}{\stackrel{\overbrace{}}{\sim}}$ & 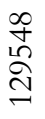 & 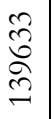 & 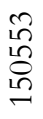 \\
\hline 2047 & $\begin{array}{l}\hat{\widehat{a}} \\
\stackrel{0}{0} \\
\stackrel{2}{\sim}\end{array}$ & $\begin{array}{l}0 \\
\stackrel{+}{+} \\
\stackrel{0}{b} \\
\infty\end{array}$ & 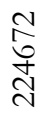 & $\stackrel{\stackrel{m}{2}}{\stackrel{n}{r}}$ & $\sqrt{6}$ & $\frac{n}{6}$ & 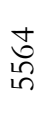 & ڤి & $\underset{\infty}{\nabla}$ & $\begin{array}{l}\text { రి } \\
\text { 뉴 } \\
\text { 으 }\end{array}$ & $\underset{\infty}{\stackrel{2}{\sigma}}$ & 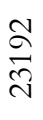 & 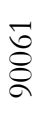 & $\begin{array}{l}\infty \\
\infty \\
\infty \\
\Xi \\
=\end{array}$ & $\stackrel{m}{\stackrel{m}{2}}$ \\
\hline 2074 & $\begin{array}{l}\stackrel{\operatorname{Ln}}{\mathbb{t}} \\
\underset{\sigma}{\sigma}\end{array}$ & $\begin{array}{l}\stackrel{\sim}{m} \\
\stackrel{\sim}{\sim} \\
\stackrel{\sim}{\sim}\end{array}$ & 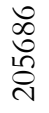 & $\stackrel{\infty}{\circ}$ & ڤె & $\stackrel{0}{i n}$ & ? & $\begin{array}{l}\text { Ln } \\
\text { nn }\end{array}$ & N & ơ & $\underset{f}{\text { f }}$ & 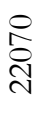 & $\frac{\stackrel{2}{8}}{\underset{7}{+}}$ & $\begin{array}{l}\stackrel{2}{5} \\
\stackrel{\aleph}{\infty} \\
\infty\end{array}$ & $\begin{array}{l}\stackrel{\hat{\sigma}}{\sigma} \\
\stackrel{\overbrace{}}{\sigma}\end{array}$ \\
\hline
\end{tabular}

Note: Numerical values for the years: 2020 (base year), 2030 (year set in development strategy of Latgale region), 2047 (middle of the forecast period), and 2074 (end of the forecast period).

Source: authors calculations using data from Official Statistics Portal, Official Statistics of Latvia, 2021a, 2021b, 2021c, 2021d. 